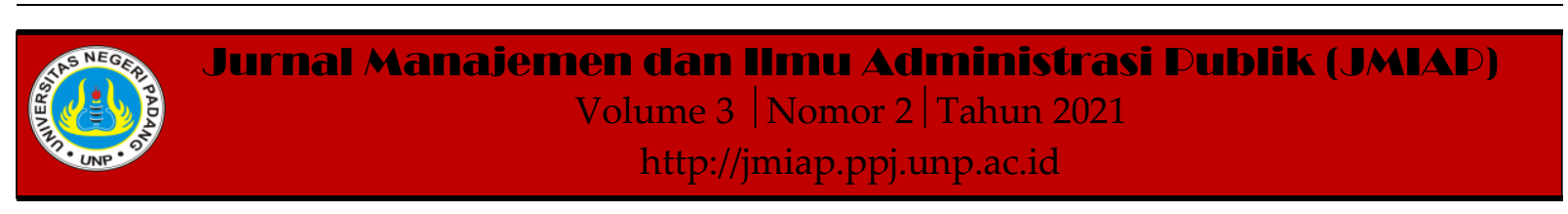

\title{
FAKTOR-FAKTOR PENYEBAB ANAK NELAYAN PUTUS SEKOLAH DI KELURAHAN PASIA NAN TIGO KECAMATAN KOTO TANGAH KOTA PADANG
}

\author{
$\operatorname{Vanessa}^{1(a)}$, Fitri Eriyanti ${ }^{2(b)}$ \\ ${ }^{1}$ Jurusan Ilmu Administrasi Negara, Universitas Negeri Padang \\ ${ }^{2}$ Jurusan Ilmu Administrasi Negara, Universitas Negeri Padang \\ a) vanessaolvanaridwan@gmail.com, ${ }^{b}$ fitri.eriyanti@fis.unp.ac.id
}

\begin{abstract}
This article describe the factors that cause fishermen children who drop out of school in Pasia Nan Tigo Subdistrict Koto Tangah Padang City. In this study, it was intended to find out what are the factors taht cause fishermen's children to drop out of school in Pasia Nan TigoVillage. This Research uses qualitative approach, and research type using descriptive method. Data collection techniques in this study through interviews, observations and documentation studies, instruments in this study are interview guidelines that have been prepared, as well as mobile phones to collect data in research. In the research data reduction can be drawn conclusions from the data taht has been obtained. The results showed that the factors that cause fishermen to drop out of school in Pasia Nan Tigo Village are the economic factors of parents, the environment,parents' awareness about the meaning of education, workfactors and interest an motivation factors.

Keywords : Causative Factors, Fishermen's Children, Drop Out of School

Corresponding author. Email.vanessaolvanaridwan@gmail.com

How to cite this article. Vanessa \& Eriyanti, F. (2021). Faktor-Faktor Penyebab Anak Nelayan Putus Sekolah di Kelurahan Pasia Nan Tigo Kecamatan Koto Tangah Kota Padang. Jurnal Manajemen dan Ilmu Administrasi Publik (JMIAP) Jurusan Ilmu Administrasi Negara Fakultas Ilmu Sosial Universitas Negeri Padang, Volume 3 (2), Hal. 100-108.

http://jmiap.ppj.unp.ac.id

Copyright@2021. Published by Labor Jurusan Ilmu Administrasi Negara FIS UNP, Padang
\end{abstract}




\section{PENDAHULUAN}

Pendidikan ialah sesuatu hal sangatlah penting dan perlu untuk dikuasai oleh setiap individu, pendidikan diartikan sebagai upaya yang secara sadar dan terencana dilakukan untuk menciptakan nuansa dan proses belajar supaya siswa dapat mengembangkan potensi yang dimilikinya agar mempunyai spritual keagamaan yang kuat, dapat mengendalikan diri, memiliki kepribadian, terencana, memiliki akhlak dan kecerdasan yang baik dan kemampuan yang diperlukan oleh individu, masyarakat serta bangsa dan negara (UU No 20 Tahun 2003). Pendidikan sangatlah penting dalam pengembangan semua bentuk kompotensi anak, pendidikan juga bertanggungjawab membentuk kepribadianya. Pendidikan juga menjadi faktor penunjang bagi seseorang untuk melanjutkan kehidupan yang lebih baik.

Sumber daya manusia yang berkualitas mampu diwujudkan berkat adanya pendidikan yang dilalui, pendidikan juga berpengaruh terhadap pembangunan suatu bangsa atau negara. Artinya, dengan pendidikan dapat mencipatakan sumber daya manusia yang berkompeten dan mahir dibidang teknologi dan ilmu pengetahuan yang sejalan dengan kebutuhan bangsa dan negara (Morin, 2017). Proses dalam pendidikan merupakan suatu proses pemberdayaan, artinya dalam pendidikan dapat mengembangkan potensi yang ada pada manusia khususnya kepada anak agar dapat menjadi individu yang dapat memberikan bantuan pemberdayaaan masyarakat dan bangsanya. Visi dari pendidikan nasional ialah untuk membentuk sistem pendidikan sebagai pranata sosial secara kokoh dalam pemberdayaan seluruh masyarakat supaya mereka dapat berkembang dan bisa jadi manusia berkualitas, bisa menyesuaikan diri dengan segala perubahan yang ada. Pendidikan nasioanl juga memiliki misi yaitu:

1. Berusaha untuk melakukan pemerataan dan perluasan dalam bidang pendidikan;
2. Memberikan fasilitas serta memberikan bantuan untuk mengembangkan potensi yang dimiliki oleh anak Indonesia mulai dini hingga akhir hayatnya agar terwujud pribadi yang gemar belajar;

3. Memaksimalkan kesiapan dalam pemberian masukan kualitas pendidikan dalam bentuk kepribadian moral anak;

4. Memaksimalkan akuntabilitas dan profesionalitas lembaga pendidikan yang menjadi pusat pemberdayaan keterampilan, ilmu pengetahuan, sikap, serta pengalaman yang didasarkan pada standar nasioanal juga internasioanl;

5. Dan meningkatkan peran aktif masyarakat didalam penyelenggaraan yang didasarkan prinsip otonomi daerah dalam konteks NKRI.

UU No 20 Tahun 2003 pasal 49 ayat 1 telah menjelaskan, bahwasanya pendidikan kedinasan dialokasikan minimal 20\% dari Anggaran Pendapatan dan Belanja Daerah (APBD) dan Anggaran Pendapatan dan Belanja Negara (APBN) dialokasikan untuk pendidikan selain gaji pendidik. Untuk meningkatkan mutu pendidikan Di Sumatera Barat, pada tahun 2020 ini, Dinas Pendidikan sedot 31 persen APBD Sumatera Barat. Dengan anggaran tersebut di harapkan pendidikan di Sumatera Barat harus lebih baik. Dalam anggaran tersebut juga terdapat alokasi dana untuk program dana BOS (Antara Sumbar, 2020). Dengan adanya alokasi dana tersebut diharapkan dapat meningkatkan mutu pendidikan dan dapat menekan angka putus sekolah di Sumatera Barat.

Namun kenyataannya masih banyak dijumpai anak putus sekolah. Di Sumatera Barat, tahun 2018/2019 jumlah anak putus sekolah masih tinggi yaitu terdiri dari 872 anak tingkat SD, 1220 anak tingkat SMP dan 509 tingkat SMA( Statistik Pendidikan, 2020). Berdasarkan data dari Dinas Pendidikan Kota Padang tahun 2018-2019 jumlah anak yang putus sekolah di Kota Padang mengalami peningkatan. Tahun 2018 anak yang putus sekolah mencapai 237 anak. Terdiri dari 86 anak tingkat SD, dan 151 anak ditingkat SMP. Sementara 
pada Tahun 2019, angka anak putus sekolah terus bertambah yaitu mencapai 338 anak. Terdiri dari 196 anak ditingkat SD dan 142 anak ditingkat SMP (Padang Ekspres, 2019).

Kelurahan Pasir Nan Tigo ialah kelurahan yang terletak di Kecamatan Koto Tangah Kota Padang yang berbatasan langsung dengan garis pantai. Kelurahan Pasir Nan Tigo mempunyai 2726 Kartu Kelarga (KK) yang 55\% penduduknya bermata pencaharian sebagai nelayan, yang meliputi nelayan tetap dan sambilan. Ratarata penghasilan nelayan baik itu buruh nelayan ataupun nelayan yang mempunyai sampan kecil yaitu $R p$ 1.650.000-2.000.000 per bulan (DKP Sumbar). Berdasarkan data yang penulis dapatkan yang dibantu oleh kelompok nelayan di Kelurahan Pasir Nan Tigo yaitu diantaranya kelompok nelayan yang berada di Pasir Sebelah, Pasir Kandang dan Pasir Jambak, pada tahun 2019 tercatat 48 anak nelayan yang putus sekolah di Kelurahan Pasir Nan Tigo.

\section{Tabel 1. Jumlah Anak Nelayan yang Putus Sekolah pada Tahun 2019 di Kelurahan Pasia Nan Tigo}

\begin{tabular}{clc}
\hline No. & Tingkat Pendidikan & Jumlah \\
\hline 1 & $\begin{array}{l}\text { Sekolah Dasar (SD) / } \\
\text { 7-9 tahun }\end{array}$ & 6 anak \\
2 & $\begin{array}{l}\text { Sekolah Dasar (SD) / } \\
\text { 10-12 tahun }\end{array}$ & 14 anak \\
3 & SLTP & 14 anak \\
4 & SLTA & 14 anak \\
\hline & \multicolumn{1}{c}{ Jumlah } & 48 Anak \\
\hline
\end{tabular}

Dapat dijelaskan bahwa pada tahun 2019 anak yang putus sekolah di Kelurahan Pasir Nan Tigo, terdapat 20 anak di tingkat SD, 14 anak dingkat SLTP, dan 14 anak Ditingkat SLTA. Anak-anak nelayan yang putus sekolah di Kelurahan Pasia Nan Tigo ikut pergi melaut atau mencari ikan bersama orang tua nya dan bahkan dengan temantemannya. Bagi masyarakat, menjadi nelayan tidak harus mendapat ilmu pendidikan dari pendidikan formal seperti sekolah. Bahkan orang yang tidak pernah mengenyam bangku pendidikan pun juga bisa menjadi nelayan dengan mendapatkan pelatihan dari orang tua dan juga dari lingkungan tempat tinggal. Selain itu, berdasarkan informasi yang penulis dapatkan, anak-anak nelayan yang putus sekolah mereka suka membuat perkempulan hingga larut malam yang dapat mengganggu ketertiban di masyarakat, sehingga nantinya bisa terjerumus pada hal-hal kejahatan seperti narkoba.

\section{TINJAUAN PUSTAKA}

\section{Konsep Nelayan}

UU No 45 tahun 2009 tentang perikanan, dijelaskan bahwa nelayan merupakan orang yang bermata pencaharianya menangkap ikan dalam memenuhi kebutuhan hidupnya yang ukuran kapalnya 5 gross ton (GT). Sedangkan menurut Windy (2013: 7) nelayan adalah masyarakat yang bertempat tinggal tidak jauh dari wilayah pesisir atau pantai dan aktif melakukan kegiatan didekat pesisir atau pantai sebagai mata pencaharian. Sedangkan menurut Nina (2016: 6) nelayan ialah kelompok masyarakat yang perlu diangkat harkat hidupnya dan perlu diberdayakan. Imron dalam Fanesa (2014) menyatakan bahwasanya nelayan ialah kelompok masyarakat tertentu yang hidupnya bergantung kepada hasil laut, baik melalui penangkapan maupun budi daya. Masyarakat nelayan umunya tinggal di pinggir pantai, sebuah lingkungan pemukiman yang berdekatan langsung dengan aktivitasnya. Dari pemaparan diatas dapat diambil kesimpulan bahwasanya nelayan adalah masyarakat yang tinggal di daerah pesisir yang menggantungkan kehidupannya kepada hasil laut yang dilakukan melalui penangkapan ikan atau melakukan budi daya.

Adiligi dalam Nina (2016: 5) mengemukakan secara umum kriteria profil nelayan yaitu:
a. Mata pencaharian umunya yaitu menangkap ikan di laut; 
b. Keterampilan yang diperoleh didapatkan melalui ikut serta pergi melaut dengan kelompoknya ataupun dari pengalamannya sebagai buruh nelayan;

c. Pekerjaannya tidak jarang bergelut dengan maut;

d. Pendapatan yang tidak menenti dikarenakan bergantung dari tangkapan yang dipengaruhi oleh musim dan angin;

e. Tidak adanya modal dan hanya bergantung kepada hasil tangkapan;

f. Hidup dari hari ke hari tanpa adanya kepastian karena pendapatan yang tidak menentu.

\section{Konsep Pendidikan}

Pendidikan ialah sesuatu hal sangatlah penting dan perlu untuk dikuasai oleh setiap individu, pendidikan diartikan sebagai upaya yang secara sadar dan terencana dilakukan untuk menciptakan nuansa dan proses belajar supaya siswa dapat mengembangkan potensi yang dimilikinya agar mempunyai spritual keagamaan yang kuat, dapat mengendalikan diri, memiliki kepribadian, terencana, memiliki akhlak dan kecerdasan yang baik dan kemampuan yang diperlukan oleh individu, masyarakat serta bangsa dan negara (UU No 20 Tahun 2003). Menurut UU No 20 Tahun 2003 dijelaskan bahwasanya fungsi dari pendidikan nasional ialah Untuk mengembangkan kompetensi serta membentuk perilaku anak dalam menciptakan bangsa yang bermartabat agar tercapainya tujuan untuk mencerdaskan kehidupan bangsa. Menurut Fuad Ihsan (2008) makna pendidikan adalah untuk upaya mengembangkan segenap potensi pembawaan seseorang baik rohani dan jasmaninya sejalan dengan norma yang berlaku di lingkungan masyarakat setempat. Dari pemaparan diatas disimpulkan bahwasanya pendidikan ialah proses bagaimana seseorang mengembangkan potensi atau kemampuan yang dimiliki baik itu dalam bentuk tingkah laku, intelektual, maupun jasmani berdasarkan nilai-nilai yang ada di lingkungan masyarakat setempat.

Fuad Ihsan (2008: 22-23) terdapat beberapa jenjang pendidikan yang perlu diikuti peserta didik dalam penyelenggaraan sistem pendidikan, terdiri dari jenjang pendidikan dasar, menengah dan pendidikan tinggi. Dapat diuraikan sebagai berikut:

1. Jenjang pendidikan dasar merupakan tempat peserta didik menuntut ilmu pengetahuan dan keterampilan serta membentuk sikap dasar yang dibutuhkan anak dan mempersiapkannya untuk mengambil pendidikan menengah.

2. Sedangkan pendidikan menengah merupakan pendidikan yang menyiapkan anak agar menjadi masyarakat yang bisa berinteraksi di lingkungannya.

3. Dan pendidikan tinggi diartikan sebagai pendidikan untuk mempersiapkan anak agar menjadi amsyarakat yang memilki kemampuan yang maksimal dan bersifat akademik yang dapat mencipatakan ilmu pengetahuan nantinya.

Menurut Fuad Ihsan (2008) dalam arti kecil atau sempit fungsi pendidikan ialah untuk membantu secara sadar terencana perkembangan baik rohani maupun jasmani peserta didik. Kemudian dalam arti luas fungsi pendidikan yaitu :

a) Untuk perkembangan pribadi anak.

b) Untuk perkembangan warga negara terutama dalam sumberdaya manusia suatu negara.

c) Untuk perkembangan kebudayaan.

d) Untuk perkembangan suatu bangsa dalam mengahadapi perubahan atau perkembangan zaman.

Visi dari pendidikan nasional ialah untuk menciptakan sistem pendidikan sebagai pranata sosial kokoh serta berwibawa dalam memberdayakan seluruh masyarakat supaya mereka dapat berkembang dan bisa jadi manusia berkualitas, bisa menyesuaikan diri dengan segala perubahan yang ada. Pendidikan nasioanl juga memiliki misi yaitu: 
a) berusaha untuk melakukan pemerataan dan perluasan dalam bidang pendidikan bagi segenap masyarakat Indonesia.

b) memberikan fasilitas serta memberikan bantuan untuk mengembangkan potensi yang dimiliki oleh anak Indonesia mulai dini hingga akhir hayatnya agar terwujud masyarakat belajar.

c) memaksimalkan kesiapan dalam pemberian masukan kualitas proses pendidikan dalam bentuk kepribadian moral anak.

d) memaksimalkan akuntabilitas dan profesionalitas lembaga pendidikan yang menjadi pusat pemberdayaan keterampilan, ilmu pengetahuan dan pengalaman serta sikap yang didasarkan pada standar nasioanal juga internasioanl.

e) dan meningkatkan peran masyarakat dalam penyelenggaraan pendidikan didasarkan atas prinsip otonomi daerah.

\section{Konsep Anak Putus Sekolah}

Menurut Bagong (2013: 359) seorang anak dikatakan apabila putus sekolah, karena ia tidak bisa menyelesaikan pendidikan disuatu sekolah dengan lengkap. Morin (2017) mengatakan bahwasanya seorang dikatakan anak putus sekolah jika berada pada kondisi apabila seseorang mengalami keterlantaran akibat perlakuan serta sikap dari orang tuanya yang tidak memperhatikan dan tidak memenuhi kebutuhan anak untuk memperoleh kehidupn yang layak. Nazili Shaleh Ahmad (2011: 1134) bahwasanya mengatakan anak putus sekolah adalah berhentinya seorang anak yang masih di usia wajib sekolah, baik ditengah-tengah semester yang disebabkan alasan tertentu yang menyebabkan anak untuk tidak melanjutkan sekolahnya.

Menurut Sarfa (2016: 98) bahwasanya anak putus sekolah ialah suatu kondisi apabila seseorang mengalami keterlantaran akibat perlakuan serta sikap dari orang tuanya yang tidak memperhatikan yang seharusnya didapat anak untuk anak memperoleh pendidikan secara layak. Dari pemaparan diatas dapat disimpulkan bahwasanya anak putus sekolah adalah anak atau murid yang tidak bisa melanjutkan atau menyelesaikan pendidikannya ke jenjang pendidikan berikutnya, dikarenakan oleh beragam faktor salah satunya faktor ekonomi keluarga yang sulit.

Marzuki dalam Bagong (2013: 359) dalam roses saat seorang anak memutuskan untuk berhenti dari pendidikannya dapat dijelaskan sebagai beriku :

a. hal ini diawali oleh tidak adanya ketertiban anak pada saat mengikuti pelajaran di sekolah, akibat kurangnya prestasi belajar di sekolah.

b. kegiatan belajar dirumah tidak tertib karena minimnya pengawasan dari orang tua.

c. kurangnya perhatian terhadap pelajaran yang lebih mementingkan kegiatan yang tidak berhubungan dengan pembelajaran, dan banyak bermain dengan teman yang sebaya.

d. dan anak putus sekolah sebagian besar berasal dari keluarga yang kurang mampu.

Menurut C.E Beeby dalam Windy (2013:14) yang menyebabkan anak putus sekolah ialah faktor ekonomi, kurangnya kesadaran orang tua tentang arti pendidikan, lingkungan, pekerjaan, dan motivasi.

\section{METODE PENELITIAN}

Dalam penelitian ini menggunakan metode penelitian kualitatif, penelitian ini dilakukan di Kelurahan Pasia Nan Tigo Kecamatan Koto Tangah Kota Padang. Penelitian ini adalah penelitian kualitatif dan dengan menggunakan metode deskriptif. Dikatakan dengan demikian karena penelitian ini menjelaskan atau mendeskripsikan suatu kejadian ataupun peristiwa yang terjadi di lapangan secara apa adanya. Basrowi dan Suwandi (2008) mengungkapkan bahwasanya penelitian kualitatif ialah metode penelitian dengan tujuan supaya penulis dapat memahami 
tentang kenyataan melalui proses berfikir induktif.

Alasan penulis memilih Kelurahan Pasia Nan Tigo, di Kelurahan ini banyak terdapat anak yang putus sekolah khususnya pada anak dimana orang tua mereka yang bermata pencaharian sebagai nelayan. Dalam penelitian ini, teknik pengumpulan data menggunakan teknik wawancara, observasi serta studi dokumentasi. Informan pada penelitian ini yaitu kepada masyarakat nelayan di Kelurahan Pasia Nan Tigo serta kepada anak nelayan yang putus sekolah di Kelurahan Pasia Nan Tigo. Guna menguji keabsahan data peneliti menggunakan triangulasi sumber. Dan untuk teknik analisis data, peneliti menggunakan cara mereduksi data, penyajian, dan verifikasi data.

\section{HASIL DAN PEMBAHASAN}

Dari data penelitian yang penulis dapatkan terdapat beberapa faktor yang menyebabkan anak nelayan yang putus sekolah di Kelurahan Pasia Nan Tigo, yang dapat diuraikan sebagai berikut:

\section{Faktor Ekonomi}

Faktor ekonomi salah satu faktor yang menjadikan anak nelayan putus sekolah. pekerjaan orang tuanya sebagai nelayan, yang mendapatkan penghasilan tidak menentu menjadi penghambat untuk anak melanjutkan pendidikan. karena kurangnya kesanggupan orang tua untuk memenuhi kebutuhan anak untuk bersekolah. Hal ini sesuai pendapat C.E Beeby dalam Windy (2013) bahwasanya faktor ekonomi keluarga menjadi salah satu faktor yang menyebabkan anak putus sekolah. Faktor ekonomi ialah faktor utama untuk melaksanakan pendidikan. Dikarenakan, ekonomi ialah persoalan utama seseorang ataupun sekolompok orang memiliki ekonomi yang terbatas untuk biaya pendidikan.

Berdasarkan hasil penelitian penulis di Kelurahan Pasia Nan Tigo, faktor penyebab anak nelayan putus sekolah di Kelurahan Pasia Nan Tigo disebabkan faktor ekonomi. Pekerjaan orang tua sebagai nelayan yang tidak pasti pendapatan nya berapa yang menyebabkan kurangnya kesanggupan orang tua untuk membiayai kebutuhan anak dalam bidang pendidikan.

\section{Faktor Lingkungan}

Lingkungan menentukan tumbuh kembang anak. karena lingkungan mempengaruhi bagaimana anak cara berperilaku, bertindak dan lingkungan juga mempengaruhi proses belajar atau pendidikan anak. Sesuai dengan pendapat C.E Beeby dalam Windy (2013) bahwasanya lingkungan ialah salah satu faktor penyebab anak putus sekolah, lingkungan adalah kondisi-kondisi dalam dunia yang dapat mempengaruhi perkembangan anak, pertumbuhan anak lingkungan sangat berpengaruh terhadap anak. Dari hasil penelitian Elsa, dkk (2019) bahwasanya lingkungan tempat tinggal anak menjadi salah satu faktor yang mempengaruhi terjadinya aktivitas belajar anak. lingkungan masyarakat dapat berperan aktif dan menentukan bagaimana proses belajar anak. apabila dilingkungan anak nyaman dan tentram maka proses belajar akan terjadi dengan baik. Namun sebaliknya, apabila dilingkungan anak banyak anak yang tidak sekolah, hal ini juga bisa menjerumuskan anak untuk putus sekolah.

Didasarkan hasil penelitian penulis di Kelurahan Pasia Nan Tigo, selain faktor ekonomi faktor penyebab anak nelayan putus sekolah di Kelurahan Pasia Nan Tigo yaitu faktor lingkungan. Lingkungan menentukan tumbuh kembang anak dan lingkungan dapat mempengaruhi cara anak berperilaku. Yang menyebabkan anak putus sekolah di Kelurahan Pasia Nan Tigo, karena teman-teman sebaya atau lingkungannya juga banyak yang sudah tidak bersekolah. Hal ini yang menyebabkan anak juga ingin berhenti sekolah karena melihat teman sebayanya dan lingkungannya juga tidak bersekolah. 


\section{Faktor Kurangnya Kesadaran Orang Tua Terhadap Pendidikan}

Kurangnya kesadaran orang tua akan pentingnya pendidikan bagi anak menjadi salah satu faktor yag menyebabkan anak putus sekolah. karena ada dari orang tua yang menganggap pendidikan itu tidak mempengaruhi bagaimana nasib anak kedepannya. Ada orang tua yang sebagai nelayan mereka berfikir, setinggi apapun anaknya untuk sekolah pada akhirnya anak mereka juga akan menjadi nelayan seperti orang tuanya. Sejalan dengan penelitian Elsa Triana (2019) bahwasanya pandangan masyarakat akan pendidikan memberikan pengaruh terhadap keberhasilan anak dalam menyelesaikan pendidikannya. Pandangan masyarakat atau orang tua yang maju, tentu menginginkan anaknya memiliki pendidikan yang lebih maju dari orang tuanya. Tidak dengan masyarakat atau orang tua yang kurang memahami pentingnya pendidikan, meraka memiliki pandangan untuk apa anaknya memiliki pendidikan tinggi tetapi pada akhirnya tidak mendapatkan pekerjaan dan hanya akan menjadi nelayan atau petani seperti mereka. Pendapat dari C.E Beeby dalam Windy (2013) masih ada masyarakat atau orang tua di Indonesia khususnya masyarakat pedesaan dan di daerah pesisir beranggapan bahwasanya pendidikan ialah tempat untuk mendapatkan pekerjaan. Orang tua yang bekerja sebagai petani atau nelayan untuk apa anaknya sekolah tinggi-tinggi tapi pada akhirnya akan menjadi nelayan atau petani seperti mereka. Anggapan seperti ini yang membuat orang tua membiarkan ketika anaknya saat menginginkan untuk tidak melanjutkan sekolah.

Berdasarkan hasil penelitian penulis di Kelurahan Pasia Nan Tigo, yang menyebabkan anak nelayan putus sekolah ialah dikarenakan kurangnya kesadaran orang tua akan pentingnya pendidikan. ketika anak ingin mengatakan berhenti sekolah orang tua tidak memberi arahan atau pemahaman kepada anak untuk tetap melanjutkan sekolahnya. Orang tua hanya membiarkan anak ketika mengambil keputusan untuk berhenti sekolah, karena orang tua berfikir sekolah tinggi ataupun tidak sekolah anaknya juga akan menjadi nelayan seperti mereka.

\section{Faktor Pekerjaan}

Faktor pekerjaan yang menyebabkan anak berhenti sekolah karena tuntutan ekonomi keluarga. Ada sebagian anak yang sudah ikut bersama orag tuanya untuk mencari nafkah untuk menambah penghasilan atau uang saku mereka. Hal ini sangat mempengaruhi anak, karena mereka berfikir untuk apa melanjutkan sekolah lagi sedangkan dengan ikut bekerja bersama orang tuanya bisa mendapatkan uang. Sejalan dengan pendapat C.E Beeby dalam Windy (2013) anak yang sudah bisa mendapatkan uang dari hasil kerjanya akan merasakan enaknya mendapatkan uang. Anak merasa tidak perlu lagi untuk melanjutkan sekolahnya karena dengan bekerja saat masih usia sekolah bisa mendapatkan uang.

Sehingga pandangannya tentang sekolah tidaklah penting lagi. dikarenakan menurut mereka dengan melanjutkan sekolah tidaklah menjamin untuk mendapatakan pekerjaan yang layak nantinya.

Berdasarkan hasil penelitian penulis di Kelurahan Pasia Nan Tigo, faktor yang menyebabkan anak nelayan putus sekolah karena faktor pekerjaan. Anak nelayan lebih bekerja atau ikut kelaut bersama orang tua atau dengan teman sebayanya, dengan itu mereka akan mendapatkan uang. Dengan sudah bisa mendapatkan uang, mereka berfikir untuk apa melanjutkan sekolah lagi, pada saat ini saja mereka sudah bisa mendapatkan uang.

\section{Faktor Motivasi dan Minat}

Motivasi atau kurangnya perhatian orang tua terhadap pendidikan anak menjadi faktor penyebab anak malas untuk pergi ke sekolah. Orang tua kurang memberikan perhatian dan dorongan kepada anak sehingga motivasi dalam diri anak menjadi berkurang untu sekolah. 
Sejalan dengan pendapat C. E Beeby dalam Windy (2013) Motivasi ialah semua hal yang menggerakkan seseorang untuk mengerjakan sesuatu. Karena apa saja yang dilakukan manusia baik itu penting ataupun tidak tentu orang tersebut membutuhkan motivasi. Rendah atau kurangnya motivasi menumbuhkan minat seseorang dalam melakukan sesuatu. Hasil penelitian dari Sarfa (2016) rendahnya atau kurangnya minat anak untuk pergi ke sekolah karena disebabkan oleh kurangnya perhatian orang tuanya dan pengaruh lingkungan sekitarnya. Hasil Penelitian Mujiati, dkk (2018) dukungan orang tua untuk memberi semangat pada anak sangat penting untuk memacu semngat anak dalam melanjutkan pendidikan, terutama bagi anak yang masih duduk di sekolah dasar. Kurangnya minat anak untuk bersekolah, bukanlah hanya datang dari orang tua tetapi juga dari anak itu sendiri.

Berdasarkan hasil penelitian penulis di Kelurahan Pasia Nan Tigo, faktor selanjutnya yang menyebabkan anak nelayan putus sekolah disebabkan kurangnya motivasi dan minat. Kurangnya dorongan dari orang tua bahkan diri sendiri yang menyebabkan minat anak dalam belajar atau melanjutkan pendidikan berkurang.

\section{PENUTUP}

Faktor-faktor penyebab anak nelayan yang putus sekolah di Kelurahan Pasia Nan Tigo Kecamatan Koto Tangah Kota Padang yaitu:

1) Karena faktor ekonomi orang tua yang belum mampu membiayai kebutuhan anaknya untuk melanjutkan pendidikan.

2) Karena faktor lingkungan, karena banyak teman sebaya atau bnayak di lingkungan anak putus sekolah juga mempengaruhi anak untuk putus sekolah.

3) Karena kurangnya kesadaran orang tua tentang arti pendidikan, ia berfikir bahwa sekolah tinggi ataupun tidak bersekolah anak mereka juga akan menjadi nelayan.
4) Karena faktor pekerjan, anak yang sudah bisa mendapatkan atau menghasilkan uang dengan pergi kelaut anak berfikir untuk apa melanjutkan sekolah lagi sedangkan dengan kelaut dapat menghasilkan uang.

5) Karena faktor motivasi, kurangnya motivasi atau dorongan yang diberikan orang tua kepada anak menyebabkan minta anak untuk belajar atau melanjutkan pendidikan jadi hilang.

\section{DAFTAR KEPUSTAKAAN}

Ahmad, Nazili Saleh. 2011. Pendidikan dan Masyarakat. Yogyakarta: Sabda Media.

Bagong, Suyanto. 2013. Masalah Sosial Anak. Jakarta: Kencana Prenada Media Group.

Basrowi., Suwandi. 2008. Memahami Penelitian Kualitatif. Jakarta: Rineka Cipta.

dkp.sumbarprov.go.id diakses 15 Desember 2019.

Elsa, Dkk. 2019. Peran Pemerintah Daerah dalam Penanganan Anak Putus Sekolah Di Kecamatan Wawonii Utara Kabupaten Konawe Kepulauan. Jurnal Ilmu Pemerintahan. Vol. 1, No. 1.

Fanesa, Fargomeli. 2014. Interaksi Kelompok Nelayan Dalam Meningkatkan Taraf Hidup Di Desa Tewil Kecamatan Sangaji Kabupaten Maba Halmahera Timur. Jurnal Acta Diurna. Vol, III. No. 3.

Fuad, Ihsan. 2008. Dasar-Dasar Kependidikan. Jakarta: PT Rineka Cipta.

Morin, Benjamin. 2017. Strategi Dinas Pendidikan Dalam Menimalisir Anak Putus Sekolah Di Kota Bitung. Skrpsi. Program Studi Ilmu Pemerintahan. Unsrat. 
Mujiati, dkk. Faktor-Faktor Penyebab Siswa Putus Sekolah. Jurnal Pendidikan dan Ilmu Pengetahuan. Vol, 18. No. 3.

Nina, Siti Salamiah Siregar. 2016. Kesadaran Masyarakat Nelayan Terhadap Pendidikan Anak. Jurnal Ilmu Pemerintahan dan Sosial Politik. Vol. 4, No. 1.

padek.co diakses 15 Desember 2019.

Sarfa, Wassahua. 2016. Analisis FaktorFaktor Penyebab Anak Putus Sekolah Di Kampung Wara Negeri Hative Kecil Kota Ambon. Jurnal Al-iltizam. Vol, 1. No. 2.

statistik.data.kemdikbud.go.id diakses 20 Juni 2020.

sumbar.antaranews.com diakses 20 Juni 2020.

UU No 20 Tahun 2003 Tentang Sistem Pendidikan Nasional.

UU No 45 Tahun 2009 Tentang Perikanan.

Windy, M. 2015. Studi tentang penyebab anak putus sekolah pada masyarakat nelayan desa ogomoli kecamatan galang kabupaten tolitoli. Jurnal Untad. Vol, 3. No. 2. 